\title{
Container maritime transport on an international scale: a choice model of service and hub port
}

\author{
F. Russo, G. Chilà \& D. Iannò \\ Università degli Studi Mediterranea di Reggio Calabria, \\ DIMET - Dipartimento di Informatica, Matematica, \\ Elettronica e Trasporti, Italy
}

\begin{abstract}
In this work we present a model to simulate container service of maritime transport on an international scale, considering the alternatives hub and spoke and point-to-point. Given the alternative hub and spoke, the choice of hub port is simulated. Several model specifications are proposed. An experimentation according to the independency of the two choices, maritime service and hub port, is carried out for the Mediterranean basin.
\end{abstract}

Keywords: freight transport, service choice, international scale.

\section{Introduction}

On an international and, especially, an intercontinental scale, freight transport via sea dominates other transport modes, as experimentally highlighted. While on an intracontinental scale, freight transport via railway is significant; on an intercontinental scale, it is not competitive. Therefore, on an intercontinental scale it is important to simulate the joint choice of transport mode/service and not only the choice of transport mode.

In most cases, the choices of container service and hub port (for transhipment service) are supposed to be independent and then probability choices are simulated according to a factorial approach. Positive results obtained according to this hypothesis shows how good this method is, even if, in order to consider the interaction between the two levels of choices, an approach simulating jointly mode/service and hub port could further improve the results. 
In this work a model simulating the container maritime transport service on an international scale is proposed, considering the alternatives, hub and spoke and point-to-point. Once the alternative hub and spoke is given, the choice of hub port is simulated.

The work is part of a two-year research project financed by the Italian Ministry of University and Research, whose general objective is to define guidelines for the competitiveness of the Italian transhipment ports of Gioia Tauro, Cagliari and Taranto in the euro-Mediterranean context. Other specific lines of research concern the development, and the application to the Mediterranean area, of aggregate procedures [1] and models [2] to estimate the demand variables of container maritime transport, and of methods to evaluate the efficiency of container transhipment ports [3].

In section 2, a synthetic state of the art related to the maritime transport service choice models on an international scale is proposed; in section 3 , the proposed model is specified; in sections 4 and 5, model calibrations for the two levels of choice obtained from an experimentation in the Mediterranean basin are reported; finally, in section 6, main conclusions and future objectives are presented.

\section{State of the arte on freight modal choice model on an international scale}

The displacements on an international scale had a significant growth in the last two decades, due to large multinationals, which, in order to take advantage of raw materials and cheap labour, have preferred to locate manufacturing plants at a considerable distance from the places of consumption.

Haralambides and Veenstra [4] propose three approaches to simulate freight demand on an international scale:

- the first approach follows the standard theory of international trade [5] which allows the indirect inclusion of transportation costs and it is based on the Ricardian principle of competitive advantage [6];

- the second approach relies on an aggregate cost function for a given industrial sector, from which a demand function for shipping is derived [7];

- the third approach is based on spatial interaction models to estimate trade flows [8-10]: the outgoing flows from the origin zone divide up the destination zones proportionately inversely with distance.

In the first approach, a more direct relationship between the international movement of freight and transportation costs is offered by Bougheas et al. [11]. The authors analyze the impact of infrastructure in a Ricardian model of bilateral trade which includes the transport cost: in the model, the infrastructure is a technology that reduces the cost (the authors assume that transport costs are inversely proportional to the level of infrastructure).

Input-output models are also used for freight transport demand estimation, both on interregional and international levels, as an extension of the third 
approach. These models are a generalization of the model proposed by Isard [12] and subsequently developed for freight transport demand [13]. In order to simulate trade between different zones, a Multi-Regional Input Output model (MRIO) with constant coefficients could be used.

Regarding transport mode choice, our literature survey highlighted the absence of models that simulate the transport mode/service and the path choices on an international scale, since, in most cases, models are referred to regional areas [14].

Coto-Millan et al. [15], for example, propose a theoretical model explaining the behaviour of imports and exports of goods by ship for a particular economy, such as the Spanish one. On this scale, the maritime transport, as first mentioned, is predominant in comparison with the other modal choice alternatives. As a result, it is necessary to simulate the choice of service, inside the maritime transport mode, with respect to modal choice, generally considered on the other territorial scales.

A mode-service choice model on a euro-Mediterranean scale is proposed by Russo and Assumma [2, 16]. The model specifies four choice alternatives: container ship, solid bulk ship, liquid bulk ship and roll on - roll off ship. Monetary cost and travel time are introduced as attributes of the level of service for each mode-service. Among the level of service attributes, the specific attributes of alternative (ASA) or modal preference can be included, taking into account the characteristics of each mode not evaluated quantitatively.

Concerning maritime services, the market offers two different services: pointto-point and transhipment. The choice of transhipment service implies the identification of the hub port.

A model of hub port choice is proposed by Park and Lim [17]. They analyse the factors causing an increase of container handling in Busan port. Veldman and Buckmann [18] analyse the competitiveness among container ports in Northern Europe.

A detailed state of the art is reported in Russo et al. $[19,20]$.

\section{Specification of the choice model of service-mode and hub port}

In this work a choice model of container service of maritime transport on an international scale is proposed, between the alternatives hub and spoke and point-to-point, and, given the hub and spoke alternative, of the hub port. These models are downstream of the freight demand models at international scale such as those proposed in Russo and Assumma $[2,16]$.

For the generic alternative of joint choice $m$ a function of generalized utility $U_{m}=f\left(U_{m, s e r v}, U_{m, h u b}\right)$ is proposed; the function includes two parts:

- $U_{m, s e r v}$, related to the attributes of main transport service m,serv;

- $U_{m, h u b}$, related to the attributes of hub port, for main transport service hub and spoke, equal to zero for main transport service point-to-point. 
This function can be specified considering the different relation among the level of choice (hierarchical or factorial) and different hypothesis on random residual distributions. They generate models classified into two main classes:

- models characterized by choice probabilities expressed in closed forms (e.g. generalized extreme value models, GEV, and their specifications Multinomial Logit and Nested Logit);

- models characterized by simulated probability choice (e.g. Probit and Mixed Logit models).

In this work the choice model is specified supposing that service choice and hub port are independent and then user choice process could be specified according to a factorial approach.

We also assume that there is independence in the choice of port for each path $\mathrm{o} / \mathrm{d}$ travelled by the same ship around the world. A different assumption can regard the sequential choice in respect to previous decisions [21, 22].

Formally, utility function of generic alternative $m, h u b$ is expressed as:

$$
U_{m, h u b}=V_{m, h u b}+\varepsilon_{m, h u b}=V_{m, h u b}+\eta_{m, \text { serv }}+\tau_{m, h u b / m, s e r v}
$$

with

$V_{m, h u b}$ part of systematic utility related to the hub port choice;

$\eta_{m, \text { serv }}$ part of random residuals related to group m,serv;

$\tau_{m, s e r v / h u b}$ part of random residuals related to hub port.

If we consider the sequential approach $[21,22]$ the utility function will be:

$$
\begin{aligned}
& U_{m, h u b}(t)=V_{m, h u b(t) / m, h u b(t-1)}+\varepsilon_{m, h u b(t)}=V_{m, h u b(t) / m, h u b(t-1)}+\eta_{m, \operatorname{serv}(t)}+\tau_{m, h u b(t) / m, h u b(t-1)}+\tau_{m, h u b(t) / m, \operatorname{serv}(t)} \\
& \quad
\end{aligned}
$$

where

$V_{m, h u b(t) / m, h u b(t-1)} V_{h u b}(t)=f\left(V_{m, s e r v}(t), V_{h u b}(t-1)\right)$ shows the relation between hub port choice in time trespect to the previous choice in time $t-1$;

$\tau_{m, h u b(t) / m, h u b(t-1)}$ part of random residuals related to dependence between hub port choice in time $\mathrm{t}$ and $\mathrm{t}-1$;

$\tau_{m, h u b(t) / m, \operatorname{ser}(t)}$. part of random residuals related to dependence between hub port choice and type of maritime service in time $t$.

Attributes considered in the choice of hub port are aggregated in classes; for each class we recall main of these:

- $\quad$ Port location

minimum deviation from the direct route between Suez and Gibraltar; distance from the geographic center of the Mediterranean basin; distance from the economic center of the Mediterranean basin; 
- Infrastructural characteristics depth of the dock ports; length of the docks to class in depth; size of the square

- $\quad$ Equipment characteristics number of cranes compatible with the size of the ship;

- $\quad$ Service characteristics

qualified staff; productivity (time while the ship is in port, the sum of the waiting time for berthing and time spent in dock); continuing time; efficiency of public services (customs, financial police, ASL, etc.).

The assumption of independence introduced between service choice and hub port allows us to subdivide the systematic utility related to a pair " $m$,serv $m$, hub" in a part related exclusively to the service choice and in a part related to the join choice service-hub:

$$
V_{m, h u b \text { m,serv }}=V_{m, h u b}+V_{m, \text { serv }} .
$$

with

$V_{m, h u b}$ part of systematic utility related to the hub port choice;

$V_{m, \text { serv }}$ part of systematic utility related to the service choice.

$V_{m, \text { serv }}$ is function, in general, of attributes related to the service and to the freight class, and of alternative specific attributes; among which:

$\begin{array}{ll}T_{m, \text { serv }} & \begin{array}{l}\text { travel time for a ship which directly link the generic pair of } \\ \text { origin/destination (o/d) ports; }\end{array} \\ C_{m, \text { serv }} & \text { unitary transport cost of a container; } \\ C l & \text { attribute function of class of freight; } \\ A S A & \text { alternative specific attribute. }\end{array}$

If we suppose that the user choice process can be specified according to a factorial approach with a Gumbel distribution of random residuals, it is possible to specify the probability to choose the joint alternative " $m$, serv $m, h u b$ " as:

$\mathrm{p}(m)=\mathrm{p}(m, \operatorname{ser} v, m, h u b)=\mathrm{p}(m, \operatorname{ser} v) \cdot \mathrm{p}(m, h u b)=$ $=\left\{\exp \left[V_{m, \text { serv }} / \theta_{0}\right] / \Sigma_{\mathrm{m}, \text { serv }} \cdot\left[V_{m, \text { serv }} / \theta_{0}\right]\right\} \cdot\left\{\exp \left[V_{m, \text { hub }} / \theta\right] / \Sigma_{\mathrm{m}, \text { hub }} \exp \left[V_{m, \text { hub }} / \theta\right]\right\}$

The following section proposes the specification and calibration of service and hub port choice probabilities. 


\section{Calibration of the choice probability of service mode}

The calibration of the proposed model, reported in this section, refers to an experiment carried out in the Mediterranean basin, where it is reasonable to assume that service and hub port choices are independent and that therefore the decision-making process can be expressed according to a factorial approach.

For the mode service choice, considered alternatives are:

- point-to-point (PP);

- hub and spoke (TR);

The proposed specification of utility function for $V_{m, s e r v}$ is reported in the following for the alternatives point-to-point (PP) and hub and spoke (TR):

$$
\begin{aligned}
& V_{P P}=\beta_{1}+\beta_{2} \cdot T_{P P}+\beta_{3} \cdot C_{P P}+\beta_{4} \cdot \text { Dep } \\
& V_{T R}=\beta_{2} \cdot T_{T R}+\beta_{3} \cdot C_{T R}+\beta_{5} \cdot \text { Short_Fedeer }
\end{aligned}
$$

where

$$
\begin{array}{ll}
T_{P, P} & \text { travel time for a ship with capacity equal to } 4.000 \text { container } \\
\text { that directly links the generic pair of origin/destination (o/d) } \\
\text { ports; } \\
\text { total time, in days, required to link a pair o/d ports, using a } \\
\text { transhipment port where containers are transferred from one } \\
\text { feeder ship to a mother ship; it was assumed that the capacity } \\
\text { of the feeder ship is of } 2.000 \text { TEU and that of the mother ship } \\
\text { of } 10.000 \text { TEU; } \\
\text { unit cost, in dollars, for the transport of a container that travels } \\
\text { on a ship of } 4.000 \text { TEUs, which directly link a pair of ports } \\
\text { o/d; } \\
\text { unit cost, in dollars, for the transport of a container that travels } \\
\text { on a } 2.000 \text { TEU ship, during the route from the port of origin } \\
\text { to the port of transhipment, and on a } 10.000 \mathrm{TEU} \text { ship, during } \\
\text { the route from the port of transhipment to the port destination; } \\
\text { the cost is the sum of the cost of sea travel and the cost of stay } \\
\text { of ships in the port of transhipment; } \\
\text { dummy variable that is a equal to } 1 \text { if the type of goods } \\
\text { transported is perishable, zero otherwise; } \\
C_{T R}
\end{array}
$$

For the model calibration, level of service attributes are estimated considering specific supply models, with cost functions related to travel time and cost [2326], which are focused on in some cases. For all the shipments to and from the 
Mediterranean basin belonging to the sample, travel times (port-port and ship's stay in port) and operating costs for transporting a TEU were calculated.

The model was calibrated in a disaggregated way, by means of a sample of 727 observations of shipments between pairs of ports.

The results (Table 1) show that the calibrated parameter values are significant and have correct sign, as regards time and cost. It is worth to highlight the importance of parameter Dep, for the alternative point-to-point. It expresses the willingness to choose this service for perishable freight and it represents the need to reduce the time and number of stops at the risk of unusable goods. The parameter Short feeder is also important, expressing the willingness to choose the transhipment service if the distances with feeder vessel are less than $20 \%$ of the total distance travelled.

Table 1: $\quad$ Calibration of choice of mode/service model.

\begin{tabular}{cccc}
\hline Attribute & Alternative & Unit & Parameter \\
\hline Modal & PP & $0 / 1$ & 1,315 \\
Time & PP, TR & Days & $-0,460$ \\
Cost & PP, TR & Euro & $-0,036$ \\
Dep & PP & $0 / 1$ & 0,904 \\
Shortfeeder & TR & $0 / 1$ & 2,025 \\
\hline N. of observations & & & 727 \\
Rho $^{2}$ & & & 0,280 \\
\hline
\end{tabular}

The calibrated models are able to reproduce the current choices and they can be used to forecast the effects of different scenarios. The scenarios are related to the characteristics of port facilities and to services and routes supplied by shipping companies.

\section{Calibration of the choice probability of hub port}

This section reports a specification of the hub port choice model and the calibrations obtained as a result of an experiment carried out in the Mediterranean basin.

The considered alternatives for the choice of port hub are 19 and they are characterized by the higher number of container handled in the Mediterranean basin.

The model has a structure which is similar to the distribution models, enabling to estimate the choice probability of a port hub between the available destinations.

The systematic utility, $V_{m, h u b}$, is a function of attributes related to each hub port.

The choice of a hub port by a shipping company depends on several factors, such as the socio-economic characteristics of the area to which the port belongs, the geographical location and the physical characteristics.

A possible specification for the hub port choice, including those in the Mediterranean basin, is the following: 
with

$$
V_{m, h u b}=\beta_{1} \cdot \mathrm{Ba}^{i}+\beta_{2} \cdot \mathrm{Km}^{i}+\beta_{3} \cdot N g r u^{i}+\beta_{4} \cdot \mathrm{Cap}^{i}+\beta_{5} \cdot \operatorname{Soc}^{i}+\beta_{6} \cdot \mathrm{Pop}^{i}
$$

$B a^{i} \quad$ length of the docks with high depth for considered port $i$, expressed in $\mathrm{km}$;

$K m^{i} \quad$ minimum distance of port $i$ from the Suez - Gibraltar route, in km;

$\mathrm{Ngru}^{i} \quad$ number of cranes in port $i$;

$\mathrm{Cap}^{i} \quad$ capacity of the yards, in TEU;

$S o c^{i} \quad$ dummy variable equal to 1 if economic, social and safety conditions in the port $i$ are standard;

$P_{o p}{ }^{i} \quad$ dummy variable equal to 1 if the population of city in which port is located is more than 1 million of inhabitants, equal to 0 otherwise;

$\beta_{1 \ldots} \beta_{6} \quad$ attribute parameters.

Attributes used for the model calibration (length docks, crane number, capacity of squares, etc.) were obtained from the database built in the behalf of research project mentioned in the introduction, whose results are reported in [27, 28]. Each port has also been associated with the number of TEUs handled in a year.

The model is calibrated by means of an aggregate approach [29], using data application on the quantity of TEUs handled in a year in the ports. We recall Russo and Vitetta [30] for the calibration of link cost functions by reverse assignment.

The results obtained (Table 2) show the importance of geographic location of each port $\left(\mathrm{Km}^{i}\right)$ and of the ownership of competitive infrastructures. In particular, it highlights the weight of the attribute related to the number of gantry cranes $\left(N g r u^{i}\right)$, having a greater allocation of quay cranes for moving a greater number of TEUs, and this has an impact on costs and productivity in the economies of scale.

Table 2: $\quad$ Results of the calibrations on the choice of port hub.

\begin{tabular}{cccc}
\hline Attribute & Alternative & Unit & Parameter \\
\hline$B a$ & $\mathrm{G}$ & $\mathrm{km}$ & 0,051 \\
$K m$ & $\mathrm{G}$ & $\mathrm{km}$ & $-0,002$ \\
$N g r u$ & $\mathrm{G}$ & Number & 0,077 \\
Cap & $\mathrm{G}$ & TEU & $7,390 \mathrm{E}-0,6$ \\
Soc & $\mathrm{G}$ & $0 / 1$ & 0,285 \\
$P o p$ & $\mathrm{G}$ & $0 / 1$ & $-0,875$ \\
\hline RMSE\% & & & $16 \%$ \\
\hline
\end{tabular}

G: generic alternative.

The results show the importance of the parameter $S o c^{i}$, with positive sign, confirming that safe working conditions and satisfactory welfare are related to an increase in production in the port. This is the case, for example, of Algeciras and Gioia Tauro, among the main Mediterranean ports. The parameter Pop $^{i}$, with negative sign, allows extrapolating the regional port effect, in order to consider only the rate of flow of transhipment that arrives or leaves each port. It is the 
case of the port of Valencia, where over 3 million TEUs are handled in a year, of which, however, only $34 \%$ are of transhipment.

\section{Conclusion and future perspectives}

In this work a general utility function for service/mode choice and for hub port choice on an international scale is proposed. At this scale, the sea is basically the only alternative transport mode, for which it should simulate the choice of service in this mode, compared to the traditional selection procedures adopted at national and regional spatial scales.

As part of the alternative sea-container it is necessary to identify the type of service used, and, in the case of scenario with transhipment, what is the hub port used.

Assuming independent choices, using a set of data on shipments between ports and container handling, an experiment for the Mediterranean basin has been proposed.

The calibrated models allowed reproduction of the current choices, both in terms of choice of mode/service, as part of the alternative containers, both in terms of choice of port hub.

The future objectives concern the models application for simulating the effects of different scenarios, which will consider different configurations of characteristics of port facilities and of services and routes supplied by shipping companies. Moreover, different hypothesis of random residual distribution will be tested, considering the sequential dynamic approach, both with Logit $[31,32]$ and with Probit [21] specifications.

\section{References}

[1] Russo F. \& Musolino G., Container maritime transport at international scale: a procedure for aggregate estimation of demand variables. Proc. of Sustainable Development and Planning V, Brebbia C. A. (ed.), WIT Press, Southampton, Boston, 2011. ISBN 978-1-84564-544-1.

[2] Russo F. \& Assumma V., Container maritime transport at international scale: a model to simulate the demand flow in the Mediterranean basin. Proc. of Sustainable Development and Planning V, Brebbia C. A. (ed.), WIT Press, Southampton, Boston, 2011. ISBN 978-1-84564-544-1.

[3] Russo F. \& Rindone C. Container maritime transport at international scale: Data Envelopment Analysis for transhipment ports. Proc. of Sustainable Development and Planning V, Brebbia C. A. (ed.), WIT Press, Southampton, Boston, 2011. ISBN 978-1-84564-544-1.

[4] Haralambides H., Veenstra A., Multivariate autoregressive models in commodity trades, 8th World Conference on Transport Research Conference, July 1998, Antwerp, Belgium, 1998.

[5] Mundell R.A., Transport costs in international trade theory, The Canadian Journal of Economic and Political Science, 23(3), 331-348, 1957.

[6] Ricardo D., On the Principles of Political Economy and Taxation, 1817. 
[7] Oum, T.H., Waters, W.G. II, Yong, J.S., A survey of recent estimates of price elasticities of demand for transport, Policy Planning and Research Working Papers, WPS 359, 1990.

[8] Wilson A.G., Urban and regional models in geography and planning, John Wiley and Sons, London, 1974

[9] Hartwick J.M., The gravity hypothesis and transportation cost minimization, Regional Science and Urban Economics, 4, 1-9, 1974

[10] Nijkamp P., (1975), Reflections on gravity and entropy models, Regional Science and Urban Economics, 5, 203-225, 1975

[11] Bougheas S., Demetriades P., Morgenroth E.L, Infrastructure, transport costs and trade, Journal of International Economics, 7, 169-189, 1999.

[12] Isard W., Interregional and regional input/output analysis: a model of a space economy. The Review of Economics and Statistics, vol. 33, n. 4, pp. 318-328, 1951.

[13] Leontief W., Costa P., Il trasporto merci e l'economia italiana. Scenari di interazione al 2000 e al 2015, Sistemi Operativi, New York-Venezia, 1987

[14] Regan A.C., Garrido P. A.. Modeling Freight Demand and Shipper Behaviour: State of the Art, Future Directions. Preprint IATBR, Sydney, 2000.

[15] Coto-Millan P., Banos-Pino J., Villaverde J. Determinants of maritime import and export functions. Transp Res E 44(4), pp. 357-372, 2005.

[16] Russo F., Assumma V. Sistema di modelli per l'analisi e la simulazione dei flussi di domanda container nel Mediterraneo. In Russo F. (Ed.) Scenari di riferimento per i porti container italiani nel sistema Euro-Mediterraneo Dati di riferimento e stato dell'arte su modelli e metodi per l'analisi di domanda e offerta. Franco Angeli, Milano, 2010.

[17] Park, N.K., Lim C.K. Port choice model of transhipment cargo using system dynamic. Proceeding of WCTR XII, Julay, Lisbon, Portugal, 2010.

[18] Veldamn S., Buckmann E.. A model on container port competition, an application for the West European Container hub-ports. Maritain Economics \& Logistics, Vol.5, n², march, 2003.

[19] Russo F., Assumma V., Chilà G., Iannò D. Stato dell'arte su modelli per la previsione dei flussi di domanda merci nei porti container hub. In Russo F. (ed.) I porti container italiani nel sistema Euro-Mediterraneo - Dati di riferimento e stato dell'arte su modelli e metodi per l'analisi di domanda e offerta. Franco Angeli, Milano, 2010.

[20] Russo F., Chilà G., Iannò D., Modello di scelta del scontainer e del porto hub per il trasporto merci a scala internazionale. In Russo F. (Ed.) Scenari di riferimento per $i$ porti container italiani nel sistema Euro-Mediterraneo - Dati di riferimento e stato dell'arte su modelli e metodi per l'analisi di domanda e offerta. Franco Angeli, Milano, 2010.

[21] F. Russo, Chilà G., Probit Sequential Model for User's Choices. In Proceedings of European Transport Conference 2008, Noordwiikerhout (NL), 2008.

[22] Russo F., Chilà G, A sequential dynamic choice to simulate demand evacuation, Proc. of Seventh International Conference on Computer 
Simulation in Risk Analysis and Hazard Mitigation, Brebbia C. A. (ed.), WIT Press, Southampton, pp. 431- 442. ISBN978-1-84564-472-7, 2010.

[23] Russo F., Trasporto intermodale delle merci. In G.E. Cantarella (ed.) Introduzione alla Tecnica dei Trasporti e del Traffico con Elementi di Economia dei Trasporti, UTET, Torino, 2001.

[24] Postorino M.N., Trasporto marittimo e idroviario. In G.E. Cantarella (ed.) Introduzione alla Tecnica dei Trasporti e del Traffico con Elementi di Economia dei Trasporti, UTET, Torino, 2001.

[25] Gattuso D., Musolino G., Modelli di costo del trasporto marittimo in container e di interscambio modale. In G.E. Cantarella and F. Russo (eds.) Metodi e Tecnologie dell'Ingegneria dei Trasporti - Seminario 2000, Franco Angeli, Milano, 2002

[26] Russo F. Sistemi di trasporto merci. Approcci quantitativi per il supporto alle decisioni di pianificazione strategica tattica ed operativa a scala nazionale. Franco Angeli, Milano, 2005.

[27] Russo F. (ed.) I porti container italiani nel sistema Euro-Mediterraneo Dati di riferimento e stato dell'arte su modelli e metodi per l'analisi di domanda e offerta. Franco Angeli, Milano, 2010.

[28] Russo F. (Ed.) Scenari di riferimento per $i$ porti container italiani nel sistema Euro-Mediterraneo - Dati di riferimento e stato dell'arte su modelli e metodi per l'analisi di domanda e offerta. Franco Angeli, Milano, 2010.

[29] Cascetta E., Iannò D. (2000). Calibrazione aggregata di un sistema di modelli di domanda merci a scala nazionale. Metodi e Tecnologie dell'Ingegneria dei Trasporti, (a cura di) G. E. Cantarella e F. Russo. Franco Angeli, pp. 156-178.

[30] Russo, F., Vitetta, A. Reverse assignment: calibrating link cost functions and updating demand from traffic counts and time measurements. Inverse Problems in Science and Engineering, 2011, Forthcoming.

[31] Russo F., Chilà G., Sequential models for mobility decisions: experimentation for vehicle holding choices. In Proceedings of European Transport Conference 2007, Noordwiikerhout (NL). CD ISBN 978-1905701-02-5, 2007.

[32] Russo F., Vitetta A., An assignment model with modified Logit, which obviates enumeration and overlapping problems. Transportation. Vol. 30, Issue 2, Pages 177-201, 2003. 